\title{
Livestock Pedigree Data Management Using Radio Frequency Identification
}

\author{
Helmy Widyantara, Harianto, Madha C. Wibowo, Rai Mardiana, Susijanto T. Rasmana \\ Department of Computer Engineering, Sekolah Tinggi Managemen Informatika dan Teknik Komputer (STIKOM) \\ Surabaya
}

\begin{tabular}{|c|c|}
\hline Article Info & ABSTRACT \\
\hline $\begin{array}{l}\text { Article history: } \\
\text { Received Jun } 12^{\text {th }}, 2015 \\
\text { Revised Aug } 20^{\text {th }}, 2015 \\
\text { Accepted Aug } 26^{\text {th }}, 2015\end{array}$ & $\begin{array}{l}\text { Boerka goat is a crossbreeding product of Australian boer goat and } \\
\text { Indonesian local kacang goat. Boerka goat produce meat better than kacang } \\
\text { goat and more suited to Indonesian climate than boer goat. In order to } \\
\text { develop an optimal boerka population, the crossbreeding process beetwen the } \\
\text { next generation has to observed very carefully. }\end{array}$ \\
\hline $\begin{array}{l}\text { Keyword: } \\
\text { RFID ear-tag } \\
\text { Boerka goat } \\
\text { Pedigree } \\
\text { Online database server } \\
\text { Website }\end{array}$ & $\begin{array}{l}\text { newborn livestock and data management system of pedigree of livestock. It } \\
\text { could help the breeder to find a perfect seed for their goat. The newborn } \\
\text { goatling will fitted with an RFID integrated electronic ear-tag. This unique } \\
\text { ID number will be sent to an online database server together with the } \\
\text { neccessary datas of the baby goat. These datas will online managed using } \\
\text { website that operated by the breeders. } \\
\text { In addition to livestock datas, the website also provides information about the } \\
\text { goat farm, the owner, and also the migration or transaction of the livestocks } \\
\text { from one to another farm or to the outside goat farm community. }\end{array}$ \\
\hline
\end{tabular}

Copyright $\odot 2016$ Institute of Advanced Engineering and Science. All rights reserved.

\section{Corresponding Author:}

Helmy Widyantara,

Department of Computer Engineering,

STIKOM Surabaya,

Raya Kedung Baruk 98, Surabaya 60298, Indonesia.

Email: helmywid@stikom.edu

\section{INTRODUCTION}

Kacang goat is a local prolific goat from East Java, Indonesia. Kacang goat has reproduction rate 1.67 each birth. A healthy female of kacang goat also could give birth three times in two years. With that rate of birth, kacang goat is a potential seeds. But on the other hand, kacang goat's body is not too big and the growth rate is not to good either [3].

On the contrary, Australian boer goat is the best meat-producing goat. The percentage of meat in the boer goat's reach 40\% - 50\% from its total body weight. Furthermore, its growth rate also very fast. It could gain $45 \mathrm{~kg}$ in six month [5].

By doing crossbreeding between boer goat and kacang goat, a new breed of goat called boerka goat were born. This boerka goat has a combination of its parents good side. Boerka goat's body is bigger than kacang goat with improvement in it's growth rate. Also, boerka goat's is more suited with Indonesian wettropical climate and moderate food quantity.

The first generation of boerka goat (F1) has genetical composition 50\% each from its parents, boer goat and kacang goat. After a tight and carefull selection process that involving some certain parameters, another crossbreeding between boerka F1 (interse mating) was done. This process is neccessary to prevent heterosis or to maintain the genetical composition of the second generation (F2) of boerka goat is alike. This process has to be done until the fifth generation (F5) to obtain a stable boerka goat population [3]. 


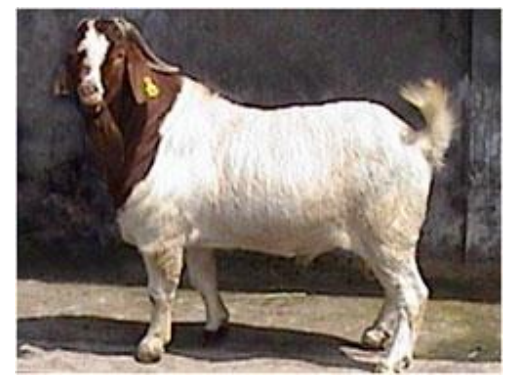

(a)

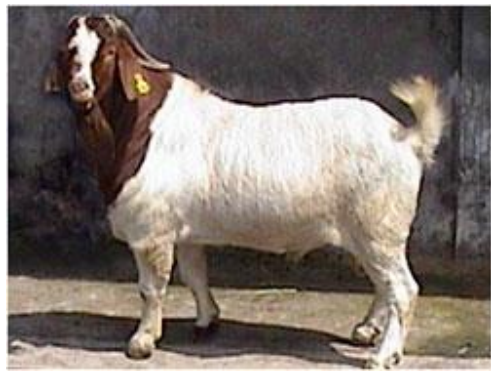

(b)

Figure 1. (a) Boer Goat and (b) Boerka Goat

There is some important factors when crossbreeding. Firstly, there should not be a inbreeding because it could lead to either genetical or physical defects to the baby [4]. Secondly, to obtain an optimal product of crossbreed, breeding process must be done during estrus and when the goat is of age to mate [1].

From those points, pedigree data and information of livestock is so important for breeders. In Indonesia, such data or information is still not managed properly. If exist, the data is also still manually recorded.

Nowadays, there is an identification device that could automatically register the datas of the livestock digitally to computer database [2]. This electronic data identification device contain a unique series of number that could be read using a certain scanner. With this device, scanned number could sent immediately together with neccessary datas of the livestocks when registering new livestocks. And so, when the ear-tag of existing livestock is scanned, the datas from the server will transfered and displayed. With such technologies as RFID, failure rate of crossbreeding caused by incorrect seed would be prevented [6].

The livestock database is online managed by each breeder in goat farms community. The information could be accessed by many people. This could facilitate anyone to find an appropriate livestock.

\section{RESEARCH METHOD}

\subsection{Designing Database}

Surveys have been done to goat farm community in East Java, Indonesia. The result are that the breeders need information about livestocks, farms, and livestock transaction. Livestocks information needed are registration number, sex, name, breed, current farm, origin farm, date of birth, birth type, description or special features, weight, and pedigree. While farms information needed are name, owner, location, contact person, and livestock population. And the transaction information needed are transaction, barter, or request for seeding.

From those informations and considering several factors, a context diagram have been made like in Figure 2 then the process is divided into several sub-process fit to hierarchical diagram like in Figure 3. Those context diagram has two external entity, that is admin and owner (pemilik peternakan), and the data flow is related to each other.

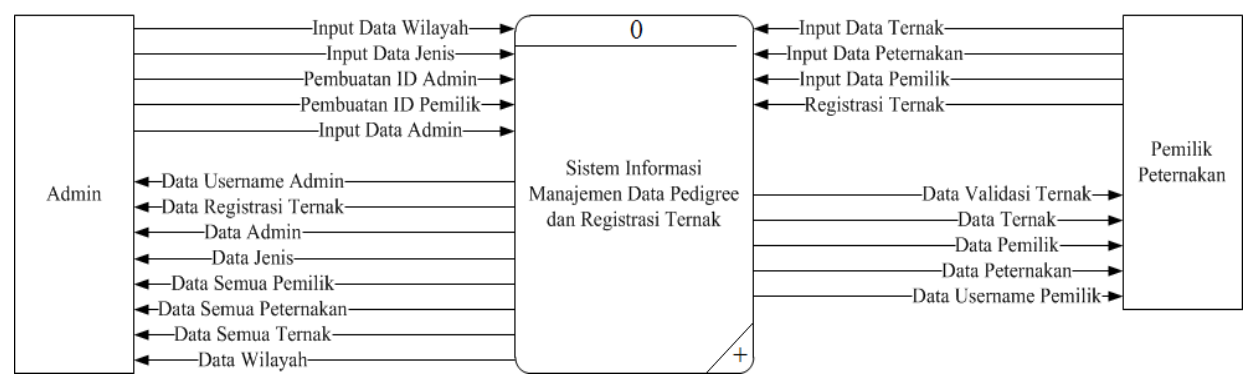

Figure 2. Context Diagram 


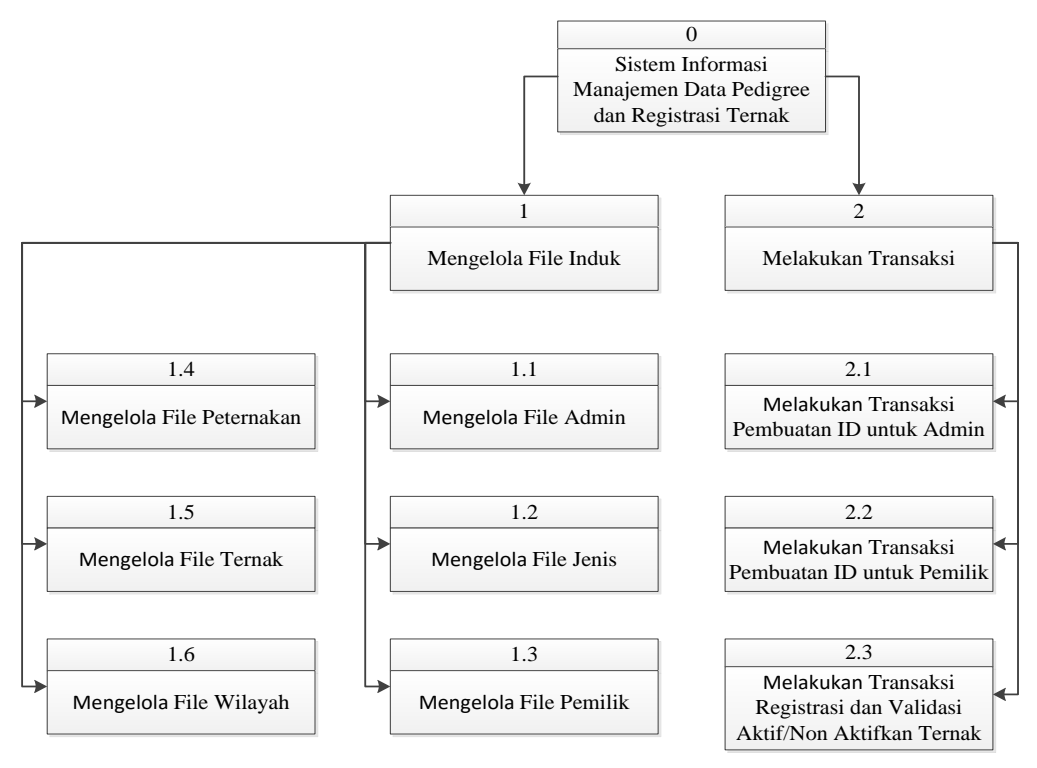

Figure 3. Hierarchical Diagram

\subsection{Livestocks Validation Using RFID Ear-Tag}

Radio frequency identification (RFID) is an identification device using radio frequency. There is an RFID transponder embedded inside the ear-tag. So the ear-tag now known as RFID ear-tag. Generally, RFID consists of two parts. The first part is the transmitter and the other one is the receiver. RFID used for this eartag is a passive RFID, which doesn't have an internal power supply. So, that RFID got the power supply from electromagnetic field emitted from antenna of RFID reader.

When the RFID ear-tag got signal from the reader, the RFID ear-tag would transmit information, in the format of 12 digit number programmed inside. Those numbers would be read by the RFID reader then sent to the computer using USB interface cable. The RFID uses a $134.2 \mathrm{kHz}$ frequency compatible with ISO11784/5 standard with FDX-B standard data format. The portable RFID reader also compatible with those standard. The RFID ear-tag and reader is showed in Figure 4.

To registering the livestocks, every newborn livestocks would be given an RFID ear-tag and its datas will be added into the online database server. Next, livestock data could be managed by each breeders. Livestock validation then could be done with scanning the ear-tag with the RFID scanner integrated to the application system. To read the RFID ear-tag, reader's position must be at least $7 \mathrm{~cm}$ from the tag. When the registration number has been read, all the livestock datas will be displayed.

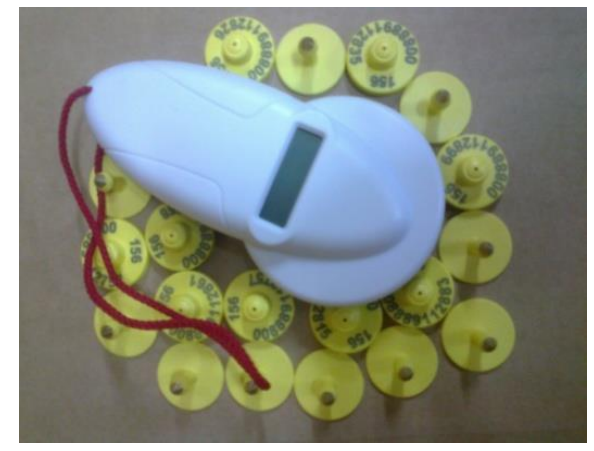

Figure 4. RFID Ear-Tag and Reader

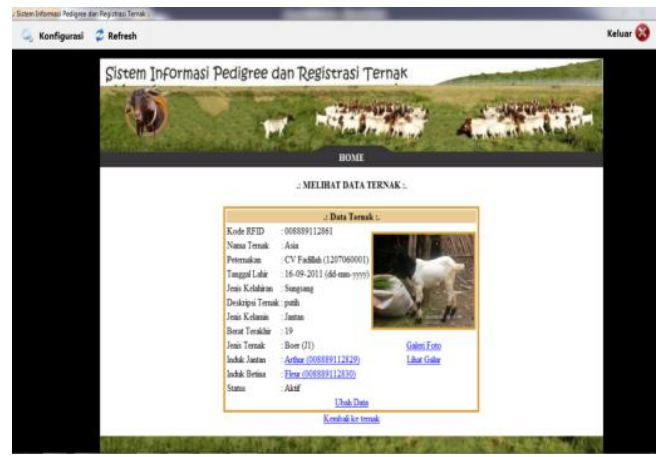

Figure 5. Result Display from Successful Read

\section{RESULTS}

The resulting application software consists of application for breeders and web-based application. The application for breeders is used to manage their goat farm and livestocks information. While the webbased application is used as information media about the goat farms and the livestocks in the community. 


\subsection{Application for Breeders}

The application for breeders is made so that it could be used to manage sent data from RFID reader via USB cable and link it with the online database server. There is also an integrated browser in this application that automatically linked to the server database.

The display of the application form is shown in Figure 5. After the configuration is set and username and password were inputed, user could use the RFID reader. When the RFID reader has successfully read the registration number on the livestock's ear-tag, the browser on the application will automatically display the livestock's datas like shown in Figure 5.

\subsection{Web-Based Application}

This web-based application is accessible using general browser. The difference from the application for breeders is user couldn't use RFID reader with this web-based application. This website contain information about livestocks, goat farms, and livestock's transactions. In general, this website contains a "Home" page, "Data Pemilik" or owner's profile page, "Data Peternakan" or goat farm's profile page, and "Informasi Permintaan" or request information page. Home page is the main page. There are two main menus, thus are data maintenance and transaction. Each of those main menu has several sub menus. On the left bar there are menus to home page and logout. The display of the home page is shown in Figure 6.

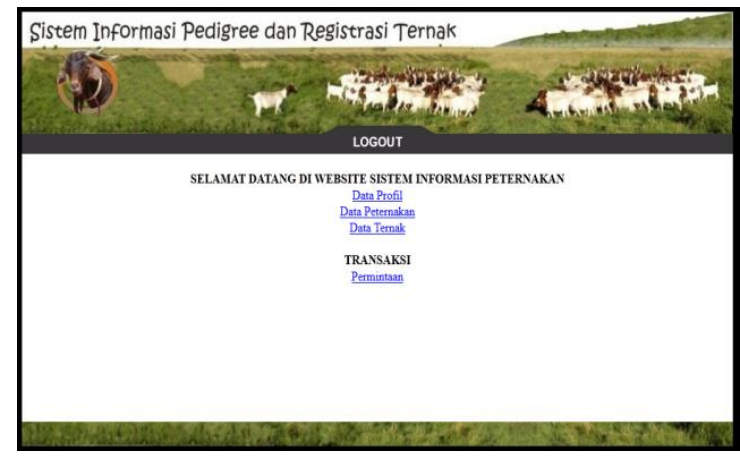

Figure 6. Home Page Display

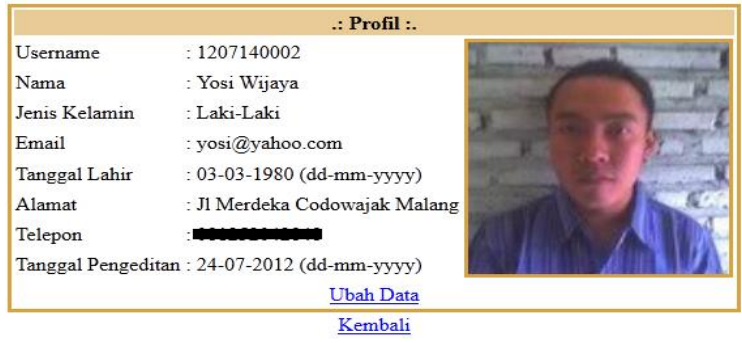

Figure 7. Owner Profile Display

.: MELIHAT DATA PETERNAKAN :.

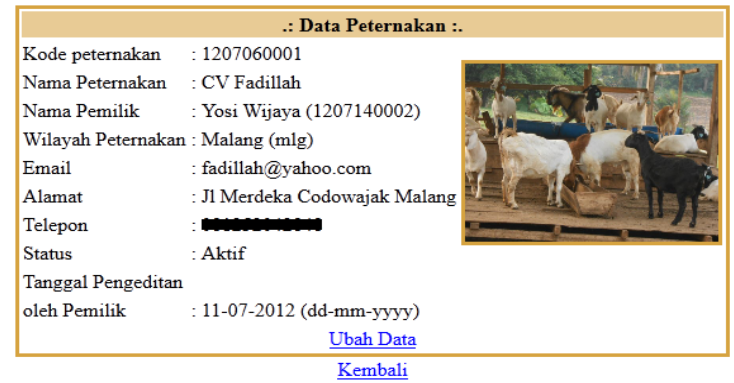

Figure 8. Goat Farm Profile Display 
Owner profile page shows the goat farm owner datas like in Figure 7. The data displayed are a neccessary datas that have been consulted with the goat farm community's owner. There are two links, "Ubah Data" to modify the owner datas and "Kembali" to go back to home page. Then in goat farm data page, the profile of the goat farm is displayed. Figure 8 shows a part of the page. There are also two links similar with links in owner profile page the difference is just the link "Ubah Data" is to modify profile of the goat farm. There is also another link in the owner's name. The link links to the owner profile page.

The "Maintenance Data Ternak" page is a page to maintain all of the livestocks datas in the certain goat farm. There are links to add new livestock as shown in Figure 9, searching livestock, and to view livestocks table. The "Tabel Ternak" page shown in Figure 10 is the table that shows all of the livestocks registered in those farm. The links beside are links to display livestocks datas, modify livestocks datas, and shows the photos of the selected livestock. The last one is the link to shows the livestocks pedigree to four generation up to it like in Figure 12.

.: MAINTENANCE DATA TERNAK :.

Untuk menambah data, isilah kolom di bawah ini, lalu klik tombol Tambah

Untuk melihat, mengubah, atou mengattifkan data, klik kata dari baris yang diinginkan yang berada di dalam tabel

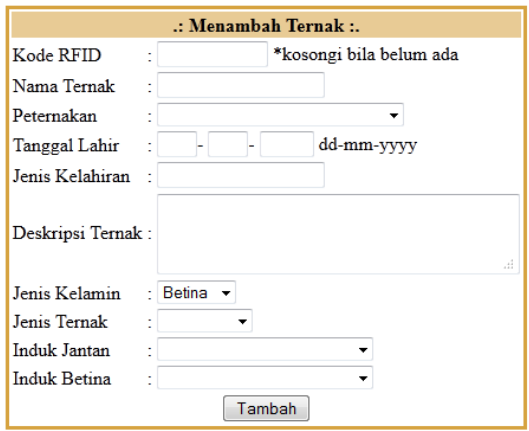

Figure 9. Display of Page for Add New Livestock

\begin{tabular}{l} 
Halaman 1 \\
\begin{tabular}{|c||c||c||c||c||c||c|}
\hline Kode RFII & Nama Ternak & Status & Lihat Data & Ubah Data & Galeri Foto & Lihat Galur \\
\hline \hline 008889112861 & Asia & Aktif & Lihat Data & Ubah Data & Galeri Foto & Lihat Galur \\
\hline \hline 008889112835 & Awall & Aktif & Lihat Data & Ubah Data & Galeri Foto & Lihat Galur \\
\hline \hline 008889112826 & Snape & Aktif & Lihat Data & Ubah Data & Galeri Foto & Lihat Galur \\
\hline \hline 008889112815 & Shadow & Aktif & Lihat Data & Ubah Data & Galeri Foto & Lihat Galur \\
\hline \hline 008889112883 & Tonya & Aktif & Lihat Data & Ubah Data & Galeri Foto & Lihat Galur \\
\hline \hline 008889112858 & Jessie & Aktif & Lihat Data & Ubah Data & Galeri Foto & Lihat Galur \\
\hline \hline 008889112752 & Rusty & Aktif & Lihat Data & Ubah Data & Galeri Foto & L Lihat Galur \\
\hline \hline 008889112829 & Arthur & Aktif & Lihat Data & Ubah Data & Galeri Foto & Lihat Galur \\
\hline \hline 008889112828 & Molly & Aktif & Lihat Data & Ubah Data & Galeri Foto & Lihat Galur \\
\hline \hline 008889112827 & Ron & Aktif & Lihat Data & Ubah Data & Galeri Foto & Lihat Galur \\
\hline
\end{tabular} \\
\hline
\end{tabular}

Figure 10. Display of The Page That Shows List of All Livestocks

$\therefore$ MELIHAT DATA TERNAK :-

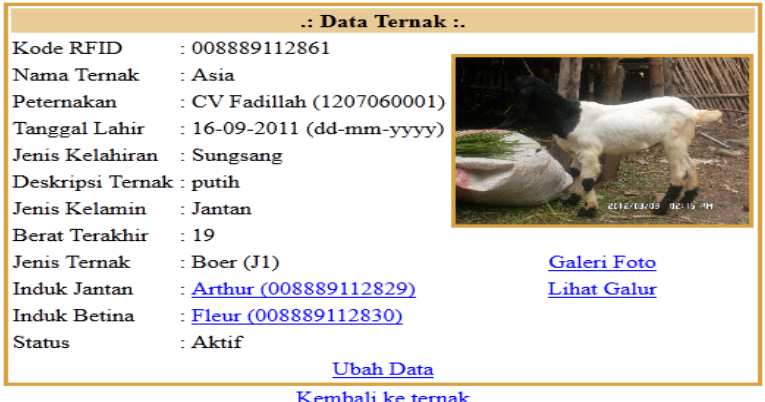

Figure 11. Livestock Profile Page Display 


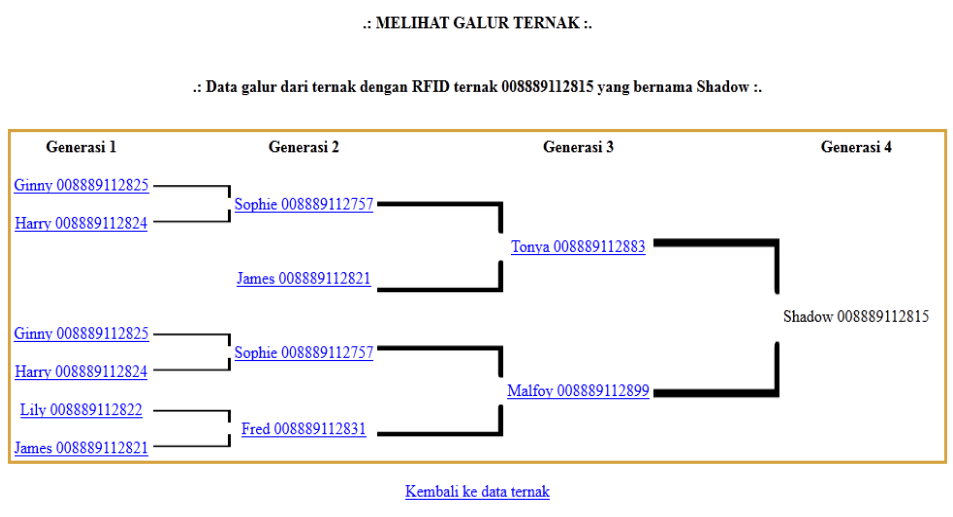

Figure 12. Livestock's Pedigree Page Display

\section{CONCLUSION}

Livestock data management system is necessary for breeders in goat farms community. In particular, the system is needed to provides information to choose the best seed for the livestocks. Best seed means not only the condition of the livestocks, moreover is the seed's pedigree. With RFID used for ear-tag, the livestock won't be swapped. It leads to the increased trust among the breeders in the community. Also, with the online website, their selling bussiness also expand. This system has been successfully served the breeders in the goat farms community to improve their farms.

\section{REFFERENCES}

[1] Bijma, P., et.al., 2001, Predicting Rates of Inbreeding for Livestock Improvement Schemes, Journal of Animal Science 2001, V. 79, P. $840-853$.

[2] Carné, S., et.al., 2010, Readability of Visual and Electronic Leg Tags Versus Rumen Boluses and Electronic Ear Tags for the Permanent Identification of Dairy Goats, Journal Dairy Science, V. 93, P. 5157 - 5166.

[3] Ginting S.P. and Fera Mahmilia, 2008, Kambing 'Boerka': Kambing Tipe Pedaging Hasil Persilangan Boer X Kacang, Wartazoa V. 18, No. 3.

[4] Muasya, T.K. et,al., 2006, Effect of Inbreeding on Growth Performance of Dual Purpose Goats in Semi-Arid Kenya. Proceedings of Kenya Agricultural Research Institute, $10^{\text {th }}$ Biennial Scientific and Agricultural Forum, $12^{\text {th }}$ to $17^{\text {th }}$ November 2006, KARI Headquarters, Nairobi, Kenya.

[5] Ted and Shipley, L., 2005, Mengapa Harus Memelihara Kambing Boer"Daging Untuk Masa Depan". Indonesia Boer Goat Breeders, (online), Malang, 2005 (http://www.indonesiaboergoat.com/ind/whyraiseboergoat.html) accessed 7 May 2010.

[6] Wang, N., et.al., 2006, Wireless Sensors in Agriculture and Food Industry - Recent Development and Future Perspective, Computers and Electronics in Agriculture, V. 50, P. 1 - 14.

\section{BIOGRAPHIES OF AUTHORS}

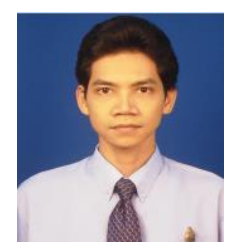

Helmy Widyantara received BE degree from STIKOM Surabaya in 2002, ME degree from Gadjah Mada University in 2010. He is currently a lecturer at Computer Engineering Department, STIKOM Surabaya, Indonesia. His research interest is in embedded system.

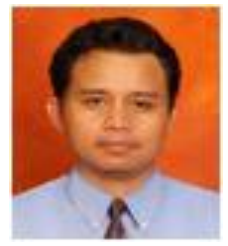

Harianto received BE degree from STIKOM Surabaya in 2002, ME degree from Gadjah Mada University in 2010. He is currently a lecturer at Computer Engineering Department, STIKOM Surabaya, Indonesia. His research interest is in intelligence control system. 


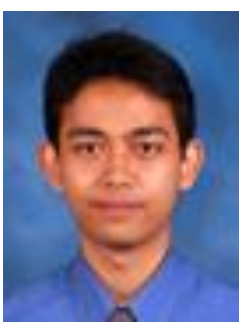

Madha Christian Wibowo received BE degree from STIKOM Surabaya in 2008, He is currently a lecturer at Computer Engineering Department, STIKOM Surabaya, Indonesia. His research interest is in computer science.

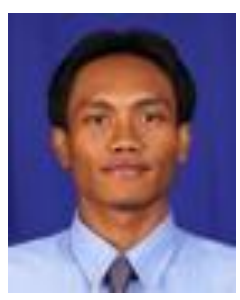

I Dewa Gede Rai Mardiana received BE degree from STIKOM Surabaya in 2005, He is currently a lecturer at Computer Engineering Department, STIKOM Surabaya, Indonesia. His research interest is in computer network.

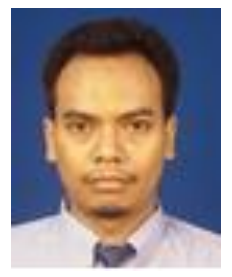

Susijanto Tri Rasmana received BE degree from STIKOM Surabaya in 2002, ME degree from Institut Teknologi Sepuluh Nopember in 2011. He is currently a lecturer at Computer Engineering Department, STIKOM Surabaya, Indonesia. His research interest is in control system. 